\title{
Effect of hydrotreating in biodiesel on the growth of deposits in the combustion chamber as a solution for the deposits reduction in the usage of biodiesel
} \author{
Ilham Attharik ${ }^{1}$, Muhamad Raihan Ariestiawan ${ }^{1}$, and Andro Cohen ${ }^{1}$ \\ ${ }^{1}$ Departement of Mechanical Engineering, University of Indonesia, 16424, Indonesia \\ ${ }^{2}$ BT2MP-BPPT, Area Puspiptek, Serpong, Muncul, Setu, South Tangerang, Banten 15310, Indonesia
}

Ary Budi Mulyono ${ }^{1,}$, Bambang Sugiarto ${ }^{1}$, Muchammad Taufiq Suryantoro ${ }^{2}$, Hari Setiapraja ${ }^{2}$, Siti Yubaidah $^{2}$, Mochammad $^{2}$

\begin{abstract}
The usage of biodiesel has been encouraged by government based on the issuance of The Regulation of Minister of Energy and Mineral Resources No. 12/2015 on the supply, utilization, and administration of biofuels as other alternative fuels. This regulation sets mandatory biodiesel mixture by 30 percent for national energy consumption by 2025 . But the usage of biodiesel with a larger percentage in diesel engines still leaves some problems with the decline of biodiesel fuel quality and the formation of deposits in combustion chamber and injectors. The purpose of this study is to compare biodiesel fuel (B20) with Hydrotreated Biodiesel (HBD) in an experiment by using fuel droplet method on a plate to observe the characteristics and mechanism of deposit formation. Plates are heated in few temperature variations in a sealed test rig so that the conditions are similar to the engine real conditions. Deposit growth of Hydrotreated Biodiesel as known as Hydrotreated Vegetable Oil (HVO) less better than Fatty Acid Methyl Ester (FAME). It may occurred because the lubricity of HVO is very low due to the absence of sulfur and oxygen compounds in the fuel, that causes oxidation that can lead to deposits in the combustion chamber.
\end{abstract}

\section{Introduction}

Indonesia has great potential in the development of processed palm oil products, one of them is biodiesel. Biodiesel is a fuel consisting of a mixture of mono-alkyl esters of long chain fatty acids, which are used as an alternative fuel for diesel engines. Biodiesel can be made from renewable sources such as vegetable oils, animal oils or from recycled oils/fats. The advantages of biodiesel oil compared to diesel oil can be viewed from the aspect of environmental friendly and reneweable. From the environmental aspect, biodiesel is known as biodegradable fuel and does not have sulfur content as diesel oil. In addition, biodiesel oil is also non-toxic and has a low $\mathrm{CO}_{2}$ emission value.

Utilization of biodiesel in Indonesia has been encouraged by the government. The use of biodiesel is expected to be an alternative solution to the availability of diesel oil is increasingly depleted., the government issued Indonesia's National Energy under Minister of Energy and Mineral Resources Regulation no. 12/2015. This regulation formalizes the promotion of biofuels in Indonesia for both ethanol and biodiesel. By 2014, the mix rate is set by the government at 10 percent for 2014 and 2015. The 2015 level is revised up to 15 percent according to the regulation, but the fact that the percentage level of the biodiesel blending rate has not been achieved. For Biodiesel 30 percent is the mandate of national energy consumption in 2025[1].

\footnotetext{
* Corresponding author: arybudimulyono1988@gmail.com
}

The use of biodiesel is very easy to apply to diesel vehicles. This is because the nature of biodiesel is easily soluble and mixed with diesel oil so it can be applied directly to diesel engines with almost no modifications. However, the use of biodiesel with a greater percentage of applications in diesel engines still leaves some problems related to the decline in the quality of biodiesel fuel and the formation of deposits in the combustion chamber and injectors [2-4]. The ease of biodiesel to degrade its quality is one factor that allegedly increases the formation of biodiesel deposits[3].

The use of fatty acid methyl ester (FAME) as a mixture of biodiesel components in vehicles is known to reduce exhaust emissions in the form of $\mathrm{CO}, \mathrm{HC}$, and PM, but raises NOx. A review of the use of biodiesel blends in high ratios in research scale has been widely practiced [5-7]. But fuel technology has made great strides in the last years and different biobased fuels show more interesting characteristics than the fatty acid methyl ester fuels (FAME). These last, in fact, present drawbacks in terms of deposits in the injection systems, engine oil dilution, biofouling, and cannot be considered as an absolute panacea to the fossil fuel dependency problem[8].

Hydrotreated Vegetable Oil (HVO) has become an attractive industrial-scale alternative to ester-type biodiesel. It can be produced from many kind of non edible vegetable oils, animal fats, waste oils and consists of a mixture of paraffinic hydrocarbons in diesel boiling 
range, free of sulfur, oxygen and aromatics. HVO has high cetane number and low density. Its bulk modulus and material compatibility is similar to petroleum diesel[8].

However, the effect of hydrotreating in biodiesel (HVO) on deposit formation has not been widely reported. The formation of deposits on machines is a fairly complex phenomenon and is highly dependent on combinations of various parameters such as fuel, material surfaces, temperature, pressure, combustion conditions, etc[9].

To solve this challenge, further research with a focus on fuel characteristics and the ability of deposit formation in engine parts is required. It should be noted that research on the formation of deposits in combustion chambers and injectors basically includes measurement of deposit thickness in engine components in response to the application of test and reference fuels $[10,11]$. The purpose of this research is to analyze the effect of hydrotreating in biodiesel (HVO) on the growth of deposits in biodiesel.

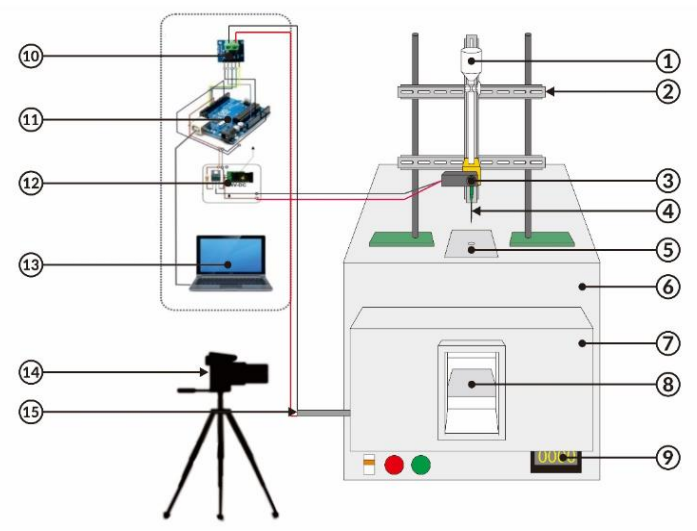

Fig. 1. Hot Chamber Deposition Test Rig.

Table 1. Caption of Hot Room Temperature Test Rig method.

\begin{tabular}{|c|c|}
\hline Number & $\begin{array}{c}\text { Caption of Hot Room Temperature Test Rig } \\
\text { method }\end{array}$ \\
\hline 1 & Fuel tank / container \\
\hline 2 & Buffer fuel container \\
\hline 3 & Solenoid Valve Shako PU220AR02-24V \\
\hline 4 & Needle \\
\hline 5 & The droplet entry holes into the furnace \\
\hline 6 & Furnace with heater capacity up to 1200 ${ }^{\circ} \mathrm{C}$ \\
\hline 7 & Furnace door \\
\hline 8 & Drip plate / heat plate (AISI 304) \\
\hline 9 & Furnace temperature control \\
\hline 10 & K type thermocouple module (Max6675) \\
\hline 11 & Arduino Uno R3 Microcontroller \\
\hline 12 & Power Supply 24 V DC \& Relay Solenoid \\
\hline 13 & $\begin{array}{c}\text { Laptop, temperature data display \& } \\
\text { microcontroller programming }\end{array}$ \\
\hline 14 & Video camera \\
\hline 15 & K type thermocouple \\
\hline
\end{tabular}

\section{System Description}

\subsection{Hot Chamber Deposition Test Rig}

Fuel was tested using a hot chamber with different plate temperatures to obtain a deposit sample as well as a method already used in a previous research [12]. This method is an approximation for real conditions of deposit formation on the surface of the engine components. This method is used to overcome the complexity to know the characteristics of deposit formation on the surface of engine components.

\subsection{Fuel Testing}

\subsubsection{Evaporation Process (Single droplet)}

The testing procedure for evaporation process is performed by setting Hot Chamber Deposition Test Rig at $450{ }^{\circ} \mathrm{C}$ for furnace room temperature setting (the average combustion temperature approach that occurs in the diesel fuel chamber). Drop plates are inserted into the furnace. Setting the heat plate temperature to $250^{\circ} \mathrm{C}$ (temperature approach on the piston ring when combustion occurs). Spray the fuel once (single droplet) on the hot plate. The evaporation process is recorded using a full $\mathrm{HD}$ video camera and evaporation time is calculated using the video that has been taken. Test continue with a hot plate temperature variation $300^{\circ} \mathrm{C}$ (temperature approximation on the injector part during combustion) $350^{\circ} \mathrm{C}$ (temperature approach on the piston head section during combustion) and repeated with the fuel variations used and different furnace temperature $\left(500{ }^{\circ} \mathrm{C}\right.$ and $\left.550{ }^{\circ} \mathrm{C}\right)$.

\subsubsection{Deposition Process (Multi Droplet)}

The testing procedure for deposition process is performed by setting Hot Chamber Deposition Test Rig. then performs a mass measurement for the drop plate. Set $500{ }^{\circ} \mathrm{C}$ for furnace temperature (the average combustion temperature approach that occurs in the diesel fuel chamber). Insert the hot plate into the Hot Chamber Deposition Test Rig and do the test fuel test stage. The droplet test step is done at 2000 drops, 4000 drops, 6000 drops, 8000 drops, and 10000 drops. In each of these drops, perform a measurement of the mass of deposits formed on the hot plate. The test is done until the it is repeated with fuel variation used and hot plate temperature variation used.

\subsubsection{Hydrotreated Biodiesel (Hydrotreated Vegetable Oil/HVO)}

In addition to FAME, HVO can be used as a mixture of biodiesel components. HVO has higher cetana numbers and higher heating value than FAME so it is expected to improve the fuel characteristics of B30 [13]. Calorific value is very influential on the performance engine. The higher the heating value of fuel, the higher the power generated. The increasingly cetane number of biodiesel blend can solve the problem of poorer self-ignitability because the ignition quality (propensity to autoignite) of the fuel is characterized by a cetane number. The 
lubricity of HVO is very low due to the absence of sulfur and oxygen compounds in the fuel. The energy density of $\mathrm{HVO}$ is also lower due to the aliphatic nature of the compounds[14].

\section{Result and discussion}

Three variation biodiesel used in this research. There are biodiesel fuel B20 FAME (research reference), biodiesel fuel B30 FAME and biodiesel fuel B30 HVO.

\subsection{Test Rig Condition}

Fuel was tested using a hot chamber with different plate temperatures to obtain a deposit sample. This test rig condition is an approximation for real conditions of deposit formation on the surface of the engine components. The room temperature in the test rig that representing the temperature of the combustion chamber in the real engine and the temperature of the plate representing the temperature at certain places within the real engine. This can be seen in table 2 .

Table 2. Single droplet yield data (evaporation).

\begin{tabular}{|c|c|c|}
\hline $\begin{array}{c}\text { Room } \\
\text { Temperature } \\
\left({ }^{\mathbf{O}} \mathbf{C}\right)\end{array}$ & $\begin{array}{c}\text { Plate } \\
\text { Temperature } \\
\left({ }^{\circ} \mathbf{C}\right)\end{array}$ & $\begin{array}{c}\text { Heat Exchanger } \\
\text { Temperature }\left({ }^{\circ} \mathbf{C}\right)\end{array}$ \\
\hline \multirow{4}{*}{450} & 250 & 227 \\
\cline { 2 - 3 } & 300 & 280 \\
\cline { 2 - 3 } & 350 & 336 \\
\hline \multirow{3}{*}{500} & 250 & 217 \\
\cline { 2 - 3 } & 300 & 271 \\
\hline \multirow{3}{*}{550} & 350 & 326 \\
\cline { 2 - 3 } & 250 & 206 \\
\cline { 2 - 3 } & 300 & 260 \\
\hline
\end{tabular}

\subsection{Evaporation Process}

The evaporation time (single droplet), tested at temperature of $250{ }^{\circ} \mathrm{C}, 300{ }^{\circ} \mathrm{C}$, and $350{ }^{\circ} \mathrm{C}$. The evaporation process of fuel on the heat plate is observed evaporative characters and evaporation time for each fuel tested at each temperature.

Depositing deposits occur when the fuel has not evaporated completely and then the next droplet has fallen back on the hot plate. This condition is also called overlapping condition. The evaporation time affects the area of the deposit and the mass of the resulting deposit.

The transition boiling regime is the zone where the fuel that is placed on the hot plate will be spherically or spherically evaporated and will be evaporated in a very fast time as illustrated in Figure 2. In the event of a transition boiling regime when the droplet falls there will be a layer vapor below A spherical droplet that will cause the droplet as it does not touch the surface of the plate and will roll off the platter. In table 3, most of fuel variation has a blue-colored cell.its means that most of the evaporation phenomena that occured are between the point of the initial boiling point (IBT) and the MEP (maximum evaporation point). At this point, fuel droplet on the hot plate evaporate slowly. At a plate temperature of $250^{\circ} \mathrm{C}$ and $300^{\circ} \mathrm{C}$, room temperature $550^{\circ} \mathrm{C}$, phenomena that occured are fire appeared.

Table 3. Evaporation time (evaporation process)

\begin{tabular}{|c|c|c|c|c|}
\hline \multirow{2}{*}{$\begin{array}{c}\text { Room } \\
\text { Tempe } \\
\text { rature } \\
\left({ }^{\circ} \mathrm{C}\right)\end{array}$} & \multirow{2}{*}{$\begin{array}{c}\text { Plate } \\
\text { Temper } \\
\text { ature } \\
\left({ }^{\circ} \mathrm{C}\right)\end{array}$} & \multicolumn{3}{|c|}{ Variations of biodiesel } \\
\hline & & $\begin{array}{c}\text { B20 } \\
\text { FAME } \\
\text { (sec) }\end{array}$ & $\begin{array}{c}\text { B30 } \\
\text { FAME } \\
\text { (sec) }\end{array}$ & $\begin{array}{c}\text { B30 HVO } \\
\text { (sec) }\end{array}$ \\
\hline \multirow{3}{*}{450} & 250 & 71,00 & 59,33 & 9,67 \\
\hline & 300 & 19,50 & 36,00 & 4,00 \\
\hline & 350 & 8,50 & 18,67 & 3,00 \\
\hline \multirow{3}{*}{500} & 250 & 40,00 & 65,33 & 6,67 \\
\hline & 300 & 16,50 & 26,33 & 4,33 \\
\hline & 350 & 16,00 & 12,00 & 2,00 \\
\hline \multirow{3}{*}{550} & 250 & 12,00 & 25,00 & 2,00 \\
\hline & 300 & 8,00 & 12,67 & 0,67 \\
\hline & 350 & 1,00 & 7,00 & 0,67 \\
\hline \multirow{4}{*}{$\begin{array}{l}\text { Explan } \\
\text { ation }\end{array}$} & & \multicolumn{3}{|c|}{$\begin{array}{l}\text { Regular evaporate / nucleate } \\
\text { boiling regime }\end{array}$} \\
\hline & & \multicolumn{3}{|c|}{ Broken / transition boiling regime } \\
\hline & & \multicolumn{3}{|c|}{ A fire appeared / oxidation } \\
\hline & & \multicolumn{3}{|c|}{$\begin{array}{l}\text { Broken and a fire appeared / } \\
\text { oxidation }\end{array}$} \\
\hline
\end{tabular}

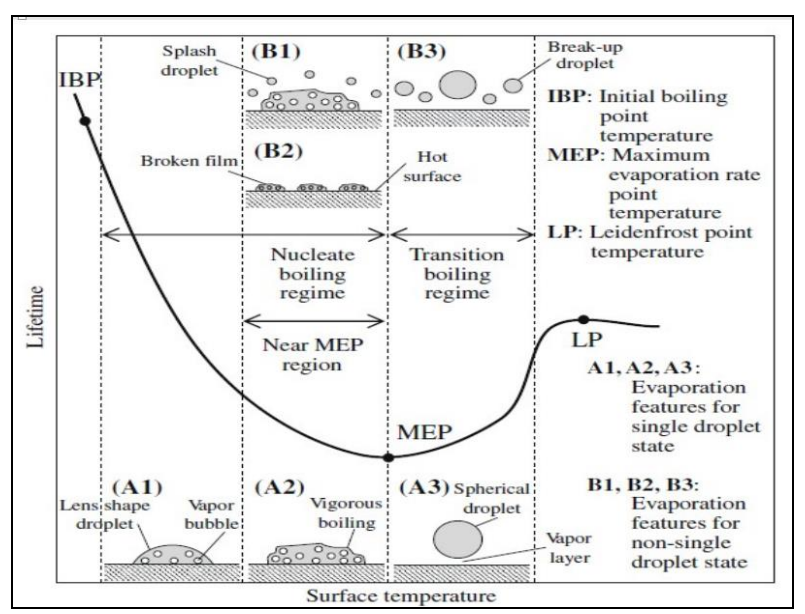

Figure 2. The fuel droplet character approaches and passes through the MEP [9]

Table 3 show a particular trend that for both all temprature plate condition and room temperatur, B30 HVO has the fastest evaporation time. At a room temperature of $550^{\circ} \mathrm{C}, \mathrm{B} 30 \mathrm{HVO}$ takes the fastest time to evaporate perfectly compared to B20 FAME and B30 FAME. While at same temperatures, the B30 FAME takes a much slower time to evaporate perfectly than B20 FAME and B30 FAME burn perfectly at plate temperature $350^{\circ} \mathrm{C}$. Table 3 also indicated there is a rupture phenomenon that occurred in transition boiling 
regime. In this phenomenon, the fuel is spherically evaporated or buckled like a ball and then evaporated in a very fast time. In this transition boiling regime, there is a layer of vapor or vapor layer between the droplets that fall with the surface of the plate so that the observation of the phenomenon that occurred droplet is like not touching the surface of the plate. This phenomenon occurred in plate temperature $300^{\circ} \mathrm{C}$ and $350^{\circ} \mathrm{C}$, room temperature $550^{\circ} \mathrm{C}$ as seen in table 3 (yellow-colored cell). Evaporation time of fuel at room temperature and biodiesel fuel can be seen as follow.

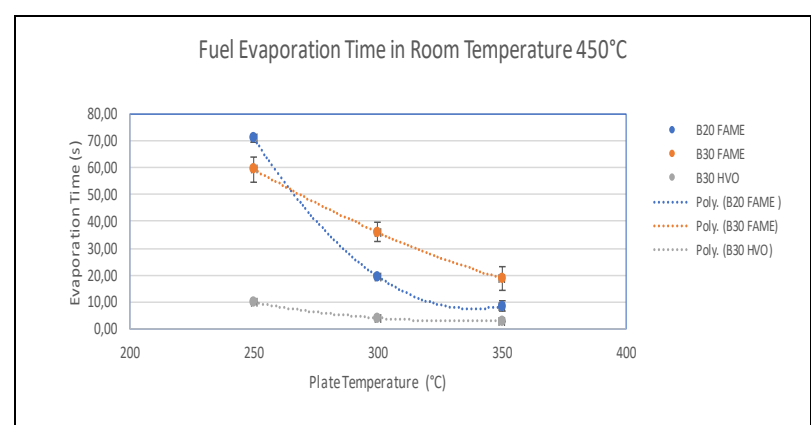

Fig. 3 Evaporation Time of Fuel at Room Temperature $450^{\circ} \mathrm{C}$.

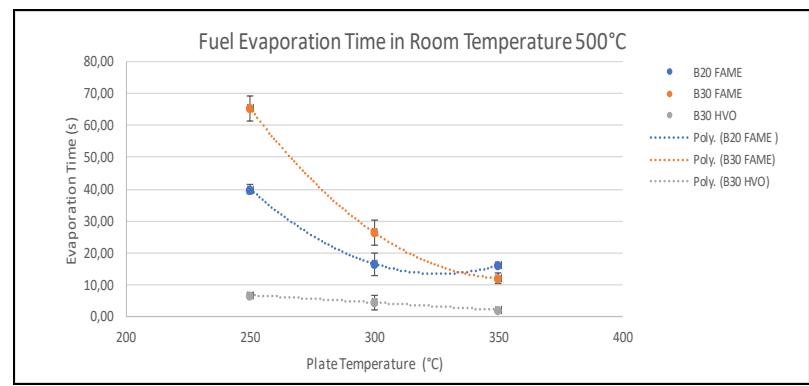

Fig. 4. Evaporation Time of Fuel at Room Temperature $500^{\circ} \mathrm{C}$.

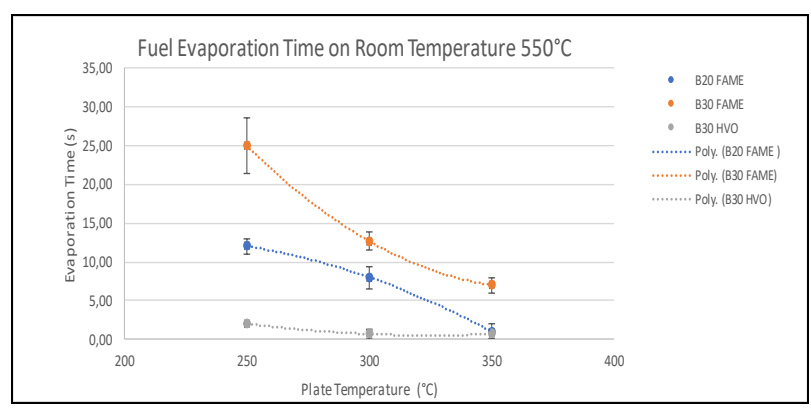

Fig. 5. Evaporation Time of Fuel at Room Temperature $550^{\circ} \mathrm{C}$.

\subsection{Deposition Process}

Deposit in combustion chamber of diesel engine consisting of carbon ash, soot, and residues of oxygenated materials. The deposit will remain on some components of the combustion chamber such as crown, rings, crevices, cylinder head and injector. Deposit growth in this component will be accumulated and have an adverse effect for engine durability. The fuel deposition process on the hot plate produces the character and growth of the deposit at each temperature. Deposit growth can be obtained by measuring the mass of the deposit (the amount of the deposit). Mass deposite growth on plate temperature and biodiesel fuel variation are as follows.

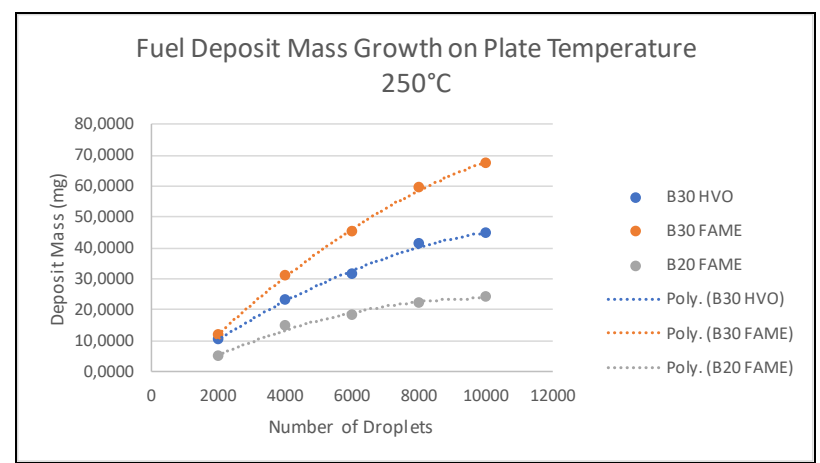

Fig. 6. Mass deposit on Plate Temperature $250^{\circ} \mathrm{C}$.

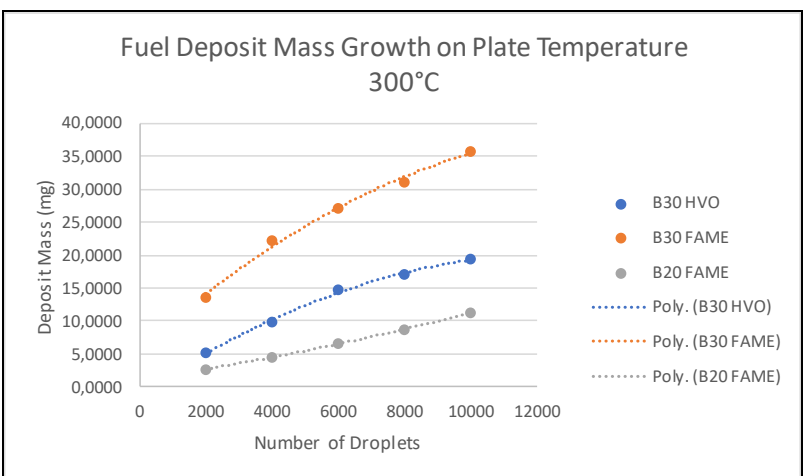

Fig. 7. Mass deposit on Plate Temperature $300^{\circ} \mathrm{C}$.

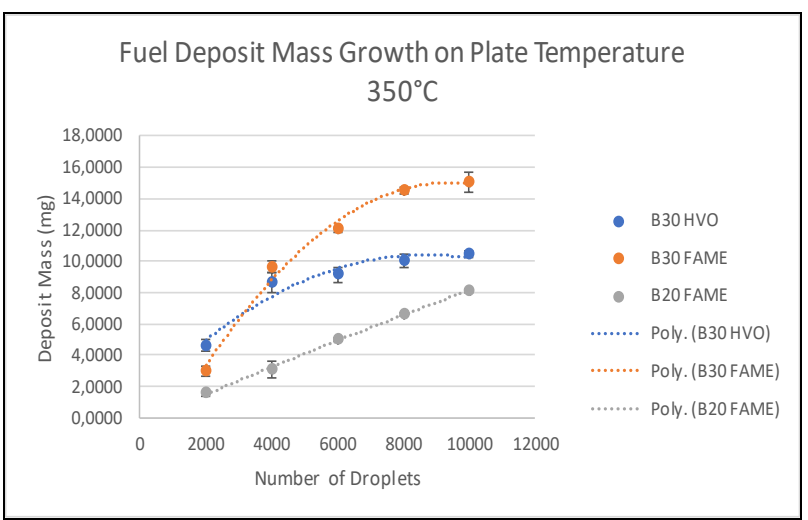

Fig. 8 Mass deposit on Plate Temperature $350^{\circ} \mathrm{C}$.

From the figure above, it can be seen that mass deposit increasing with increasing number of droplets. The highest mass deposit growth happened in B30 FAME on all temperature plate. It is conclude that B30 HVO deposit growth much better than B30 FAME. It may occurred because the lubricity of HVO is very low due to the absence of sulfur and oxygen compounds in the fuel, that causes oxidation that can lead to deposits in the combustion chamber. Beside that, according to Yusmady's research [9] the speed of droplet fuel evaporation attached to the hot wall is the most important factor of excessive deposit formation. From the figure above, for the trendline charts of $\mathrm{B} 30 \mathrm{HVO}$ fuels (at plate temperature $350^{\circ} \mathrm{C}$ start decrease the deposit mass as it passes 8000 drops, this reinforces the potential for deformation process (deposit release) to 
occur. This phenomenon also need to get a special study to know deposit characteristics for biodiesel in higher number of droplet (above 10000 droplets).

\section{Conclusion}

In this paper, forming of deposits from biodiesel with different variation, B20 FAME, B30 FAME and B30 HVO will be observed with hot surface plate methode to find their characteristics and growth mechanisms of deposits from every biodiesel variation. Based on the results shown above, it can concluded that the evaporation time affects the amount of deposit formed. Beside that, temperature difference becomes one of the causes of the amount of deposit generated. The lower the component temperature in the combustion chamber may be an indication that a higher deposit will arise. Deposit growth of B30 HVO less better than B30 FAME. It may occurred because the lubricity of HVO is very low due to the absence of sulfur and oxygen compounds in the fuel, that causes oxidation that can lead to deposits in the combustion chamber. In higher number of droplet, B30 HVO showed larger potential of deformation process (deposit release) to occur. It needs to get a special study to know deposit characteristics for B30 HVO in higher number of droplet.

The author would like to especially thank to Universitas Indonesia for PITTA Grant 2018 (Contract no. 2392/UN2.R3.1/HKP.05.00/2018) as a funding research so that this research goes well. The author also would like to thank Mr. Bambang Sugiarto as mentor for his guidance in the research, Mr. Hari Setiapraja, Mr. Muchammad Taufik Suryantoro, and Mrs. Siti Yubaidah who provides access to the use of BTMP laboratory, and to Mr. Mochammad Ilham Attharik, Mr. Muhamad Raihan Ariestiawan and Mr. Andro Cohen as a team of researchers who participated in the research.

\section{References}

1. S.S. Wirawan and A.H. Tambunan, The current status and prospects of biodiesel development in Indonesia: A review, Presented on the Third Asia Biomass Workshop,(2006)

2. A. Liaquat, H. Masjuki, M. Kalam, M. Fazal, A.F. Khan, H. Fayaz M. Varman, Impact of palm biodiesel blend on injector deposit formation, Applied Energy 111 882-93 (2013)

3. T. Omori, A. Tanaka, K. Yamada S. Bunne, Biodiesel deposit formation mechanism and improvement of Fuel Injection Equipment (FIE), SAE Technical Paper) (2011)

4. S. Jain M. Sharma, Stability of biodiesel and its blends: a review, Renewable and Sustainable Energy Reviews 14 667-78 (2010)

5. S. Bari, Performance, combustion and emission tests of a metro-bus running on biodiesel-ULSD blended (B20) fuel, Applied Energy 124 35-43 (2014)

6. G. Thompson, J. Nuszkowski, Neat fuel influence on biodiesel blend emissions, International Journal of Engine Research 11 61-77 (2010)
7. K. Okamoto, M. Kohakura, T. Kaneko, K. Fukuda, K. Furui, M. Okada, K. Tsuchihashi, K. Hirata, H. Baba T. Hasegawa, Impact Study of High Biodiesel Blends on Exhaust Emissions to Advanced Aftertreatment Systems, SAE Technical Paper (2010)

8. P. Napolitano, C. Guido, C. Beatrice L. Pellegrini, Impact of hydrocracked diesel fuel and Hydrotreated Vegetable Oil blends on the fuel consumption of automotive diesel engines, Fuel 222 718-32 (2018)

9. Y.M. Arifin M. Arai, The effect of hot surface temperature on diesel fuel deposit formation, Fuel $\mathbf{8 9}$ 934-42 (2010)

10. M.T. Suryantoro, B. Sugiarto, D. Chistian, B. Samudra, Z. Gusfa, Deposit Characterization of a Diesel Engine Combustion Chamber by Droplets at Hot Chamber Temperature: Effect of Temperature on Evaporation Time and Deposit Structure, International Journal of Technology 7 1372-80 (2016)

11. M.T. Suryantoro, B. Sugiarto, F. Mulyadi, Growth and characterization of deposits in the combustion chamber of a diesel engine fueled with B50 and Indonesian biodiesel fuel (IBF), Biofuel Research Journal 3 521-7 (2016)

12. B. Sugiarto, M. Suryantoro, S. Yubaidah M. Attharik, The effect of antioxidant additives on the growth of deposits on the use of biodiesel fuel (B100) at certain temperatures, IOP Conference Series: Earth and Environmental Science: IOP Publishing) p 012075 (2018)

13. D. Kim, S. Kim, S. Oh S.Y. No, Engine performance and emission characteristics of hydrotreated vegetable oil in light duty diesel engines, Fuel $\mathbf{1 2 5}$ 36-43 (2014)

14. M. Lapuerta, M. Villajos, J.R. Agudelo A.L. Boehman, Key properties and blending strategies of hydrotreated vegetable oil as biofuel for diesel engines, Fuel processing technology 92 2406-11 (2011) 